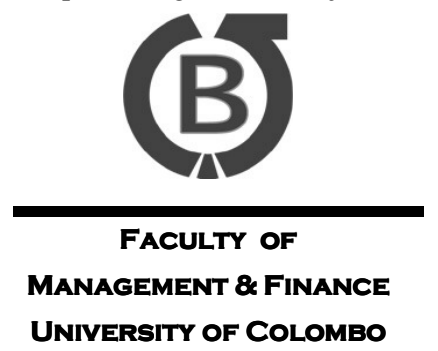

Colombo

Business

Journal

INTERNATIONAL JOURNAL OF

THEORY \& PRACTICE

Vol. 08, No. 02, December, 2017

\title{
Effect of Information Access through Social Capital on Mitigating Business Opportunism of Small Enterprises in Sri Lanka
}

\author{
H. M. S. Priyanath ${ }^{a 1}$, S. P. Premaratne ${ }^{b}$ \\ ${ }^{a}$ Department of Economics and Statistics, Sabaragamuwa University of Sri Lanka, Sri Lanka \\ ${ }^{b}$ Department of Economics, University of Colombo, Sri Lanka
}

\begin{abstract}
The study explored how information access through different dimensions of Social Capital (SC) (structural, relational and cognitive) affects the mitigation of business opportunism. Data were collected from 373 Small Enterprises (SEs) in Sri Lanka, conducting face-to-face interviews with the owners of SEs. Partial Least Squares-Structural Equation Modelling (PLS-SEM) was employed to analyse data. The results revealed that information accessed through different dimensions of SC have significant negative effects with business opportunism of exchange partners. Therefore, the study recommends SEs to develop SC while having strong relationships with exchange partners in order to access information leading to the mitigation of opportunism of exchange partners.
\end{abstract}

Keywords: Information, Opportunism, Small Enterprises, Social Capital, Transaction Costs

\section{Introduction}

According to the Transaction Costs Economics (TCE), many business exchanges are characterized by incomplete, imperfect or asymmetrical information occurred in imperfect market (Hobbs, 1996). Information incompleteness refers to the situation where all parties to a transaction face incomplete levels of information (Williamson, 1981). Asymmetrical information encourages exchange partners to behave opportunistically (Williamson, 1981). Opportunism refers to self-interest seeking by actors and to their calculated efforts to mislead, distort and disguise

1Corresponding Author: priya@ssl.sab.ac.lk

iD https://orcid.org/0000-0003-0455-2534

This work is licensed under a Creative Commons Attribution 4.0 International

License. 
information (Williamson, 1985). Opportunism includes guile in pursuit of one's own interests. This does not imply that all those involved in transactions act opportunistically always; rather, it recognizes that the risk of opportunism is often present. Williamson (1979) explained that opportunism is a central concept in the study of Transaction Costs (TC), and it is especially important for economic activity that involves transaction-specific assets in human and physical capital. Therefore, transactions tend to become costly due to opportunism of exchange partners.

Small Enterprises (SEs) have higher TC compared to large firms because they suffer hazards from opportunism of exchange partners due to asymmetrical information (Carmel \& Nicholson, 2005; Nooteboom, 1993). They do not have the capacity to collect and evaluate information due to various barriers including geographical ones in remote areas with poor infrastructure facilities, lack of knowledge to access and assess information, of time and capacity to gather and handle information, of resources to access and evaluate information, of knowledge and experience to avoid opportunism of exchange partners (Carmel \& Nicholson, 2005; Nooteboom, 1993; Spraakman, 1997). Further, SEs do not have sufficient resources to use legal contracts to safeguard their transaction from opportunism (Spraakman, 1997) and to recruit specialists to make good decisions on searching and evaluating information (Carmel \& Nicholson, 2005; Nooteboom, 1993). Therefore, the TC and the failure rate of SEs are very high (Agwu \& Emeti, 2014; Carmel \& Nicholson, 2005; Fatoki, 2011; Nooteboom,1993).

Some studies (Bhagavatula, 2009; Lu, Feng, Trienekens, \& Omta, 2012 Lu, 2007; Priyanath \& Premaratne, 2015) have underlined that SEs use their informal and personal connections in order to get required information and resources. These informal and personal connections do not have formal and written agreements but these connections are based on network relationships with family members, relatives, friends, supportive institutions and the others (Bhagavatula, 2009; Lu, 2007; Priyanath \& Premaratne, 2017a). Literature describes that the network relationship i.e. network size and density, strength of ties, relational qualities (interpersonal trust, relational norms) and common understanding among members lead to generate SC (Bhagavatula, 2009; Lu, 2007; Nahapiet \& Ghoshal, 1998). The key benefit of $\mathrm{SC}$ is that it facilitates the reach of information and increases the quality and relevance of information (Adler \& Kwon, 2002; Burt, 1992; Granovetter, 1983). Thus, SC facilitates the access of information reducing information asymmetry (Bwalya, Mugisha, \& Hyuha, 2013; Priyanto, Mazkie, \& Khusaini, 2014) and helps SEs to mitigate information asymmetry enabling the access of 
information leading to the mitigation of the opportunism of exchange partners (Henningsen \& Henning, 2013; Richman, 2006).

In literature, some scholars (Adler, 2001; Chow \& Chan, 2008; Dyer, 1997: Inkpen \& Tsang, 2005; Mysen, Svensson, \& Payan, 2011) discussed that the trust among businesses are associated with opportunism and a few researchers (Bhagavatula, 2009; Gulati \& Singh, 1998; Li \& Luo, 2011) analyzed the relationship between network relationships and opportunism. Some scholars (Artz \& Brush, 2000; Dyer \& Chu, 2003: Heide \& John, 1992; Rokkan, Heide, \& Wathne, 2003) examined the interaction between relational norms and opportunism. However, there is dearth of a complete academic work, particularly on SEs in LDCs pertaining to the examination of how information access through SC affects the opportunism of exchange partners, representing a significant gap in the literature. Therefore, this study attempted to investigate how information access through SC affects the opportunism of exchange partners, particularly SEs in Sri Lanka, in order to bridge this gap. Identifying the effect of information access on opportunism of exchange partners through Structural Social Capital (SSC), Relational Social Capital (RSC) and Cognitive Social Capital (CSC) was the specific objective of the study.

The rest of the paper is organized as follows. The next section briefly presents the theoretical base for opportunism and SC and combines them in a theoretical model. Then hypotheses have been developed using literature. In the next section, the research methodology is discussed including the research approach, sample, measurements and analysing techniques. This is followed by hypothesis testing with the use of partial least square structural equation modelling. Then results are discussed with comparisons to literature. The paper concludes by highlighting the contributions of the study and identifying some implications for policy makers.

\section{Literature Review and Hypotheses}

Information asymmetries lead to opportunistic behaviour in two ways: ex-ante opportunism (hidden information) and ex-post opportunism (hidden action) (Balakrishnan \& Koza, 1993). Ex-ante opportunism, where information is hidden prior to a transaction, is the phenomenon of misdirecting other organizations based on an organization's private information that is not shared with other organizations in the transactions. It refers to incomplete or distorted disclosure of information, especially calculated efforts to mislead, distorts, disguise, or confuse transacting parties (Williamson, 1993). Ex-post opportunism is post-contractual opportunism 
(moral hazard) in the presence of unobservable asymmetric information. This is expost opportunism which occurs after a transaction because of the hidden actions of individuals or firms. These parties may have the incentive to act opportunistically to increase their economic welfare because their actions are not directly observable by other parties (Hobbs, 1996). Therefore, opportunism of the exchange partners leads to avert the efficient decision on transaction which affects the increase of TC. If opportunism between partners exists, transactions could not be efficiently organized (Hobbs, 1996). One partner can take more benefits than the other. The suffering partner needs to make higher costs to search for information and evaluate the information in order to avoid opportunism (Dyer, 1997; Hobbs, 1996). Thus, opportunism has a positive relationship with TC (Dahlstrom \& Nygaard, 1999).

Meanwhile, some scholars (Adler, 2001; Chow \& Chan, 2008; Dyer, 1997: Heide \& John, 1992: Inkpen \& Tsang, 2005; Nahapiet \& Ghoshal, 1998) explained that SC facilitates to access information. Dyer (1997) and Heide and John (1992) empirically observed that information exchange between exchange partners reduced information asymmetry. Nahapiet and Ghoshal (1998) presented that inter-personal trust among network members encourages cooperation facilitating the access of information. Network members who trust each other are more willing to share information since they have no fear of being exploited by the other members. Hence, inter-personal trust that leads to share information generates strong cooperation among them. Dyer (1997) empirically observed that information exchange between exchange partners reduced information asymmetry and subsequently the potential for opportunism. Achrol and Gundlach (1999) have emphasized that SC is a useful resource to mitigate opportunism; Dahlstrom and Nygaard (1999) justify empirically that opportunistic behaviour consistently increases TC, and cooperative interaction among exchange partners reduces opportunism. Kale, Singh and Perlmutter (2000) indicated that SC based on mutual trust creates a basis for learning and knowledge transfer across the exchange interface and reduces opportunistic behaviour. Yenidogan (2013) highlighted the positive effects of trust on ex-post opportunism. Trust can provide an effective governance safeguard for transaction-specific investments when creating strong disincentives against opportunism (Dyer \& Singh, 1998; Zaheer \& Venkatraman, 1995; Zaheer, McEvily, \& Perrone, 1998). Trust facilitates conflict resolution by encouraging cooperative orientation between parties to adapt to the changing environmental situations (Zaheer et al., 1998) and hence reduces the residual risk for opportunism. Thus, many scholars have explained that different dimensions of 
SC facilitate the sharing of information that leads to mitigate opportunism of exchange partners.

$\mathrm{SC}$ is the value and resources that generated from inter-personal relationships. Coleman (1988) claimed that unlike other types of capital, SC is the structure of relations between actors and among actors. According to Putnam (1995), key features of SC are: a) moral obligations and norms, b) social values (especially trust) and c) social networks (especially, voluntary associations) all facilitate coordination and cooperation for the mutual benefit. SC consists of features of relationships among individuals such as networks, high levels of interpersonal trust and norms of mutual supports which act as resources for individuals and facilitate collective action (Adler \& Kwon, 2002; Burt, 1992; Nahapiet \& Ghoshal, 1998).

SC has three dimensions; structural, relational and cognitive (Nahapiet \& Ghoshal, 1998). Resources that are generated due to the pattern of relationships among individuals are called SSC. The SSC discusses the pattern of connections among the members of the network. Important aspects of the SSC are the patterns of ties between the members of a social network; network structure is based on density of ties and frequency of connectivity and interaction (Nahapiet \& Ghoshal, 1998). Thus, scholars (Babaei, Ahmad, \& Gill, 2012; Bhagavatula, 2009; Priyanath \& Premaratne, 2017b) highlighted that network size (total number of actors that the focal firm is connected to) and the density of network (existing connections out of potential ties) are the two reflective dimensions of SSC.

The RSC refers to resources that are generated from the value of relationships among individuals. The value of relationship is reflected by the strength and qualities of the relationships (Bhagavatula, 2009). The RSC has two broad dimensions: a) strength of relationships and b) qualities of relationships which are reflected by inter-personal trust (the willingness to be vulnerable to another person) (Fukuyama, 1995), norms (generalized expectations of behaviour, such as norms of reciprocity, flexibility, solidarity, reciprocity and role of integrity) (Dyer \& Chu, 2003; Rokkan et al., 2003; Wu \& Choi, 2005).

CSC is the resources that provide shared vision or common understanding among network members (Nahapiet \& Ghoshal, 1998). From a business perspective, CSC implies the value of common understanding among exchange partners (Chow \& Chang, 2008). This aspect of social capital consists of values 
such as common vision that supports a common understanding of shared goals, norms of action and social trust in a social setting (Tsai \& Ghoshal, 1998). The way that the network members show their norms, trust and commitment in reality is the CSC (Kitapci, 2016).

The conceptual research model of the study is developed synthesizing both the TCE and the SC theory. As explained above, the three dimensions of SC represent the independent variables while opportunism represents the dependent variable. Thus, the conceptual research model (see Figure 1) displays how each dimension of $\mathrm{SC}$ affects the opportunism of exchange partners. Thus, this conceptual research model helps to provide answers for the research question: how SC affects opportunism?

\section{Figure 1: Conceptual Model}

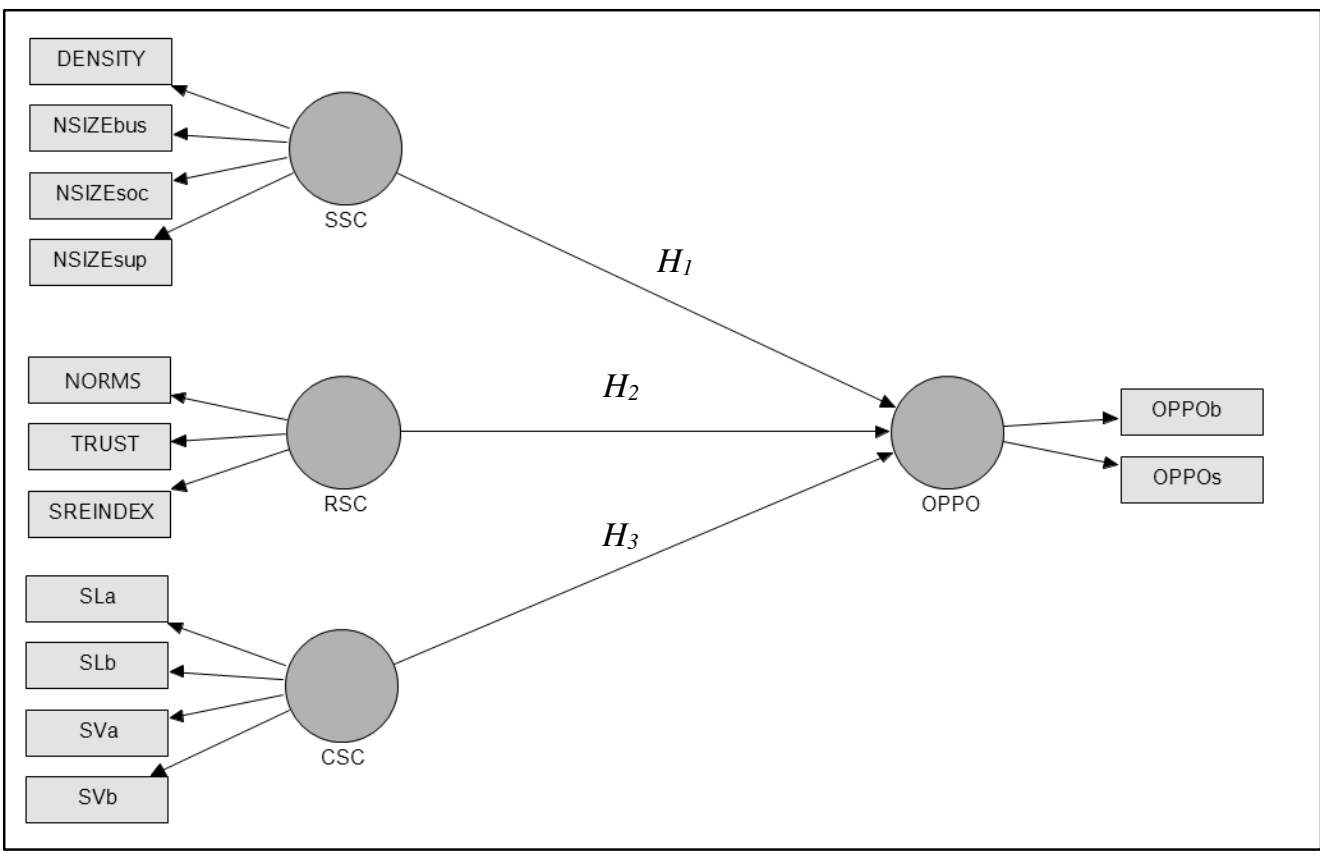

\section{SSC and the Opportunism of Exchange Partners}

SEs access information about reliable exchange partners and contact them through the network structure. They can gather information through their network as to whether the right exchange partner is selected to carry out a transaction. A network structure enables SEs to gather information, and is important to identify each other's reliabilities (Gulati, 1995). Thus, the network structure helps to access 
information about exchange partners leading the decrease of the potential risk of opportunistic behaviour of exchange partners (Carey \& Lawson, 2011; Granovetter, 1985). Frequent and close interactions between exchange partners permit them to know one another and to develop a relationship with good faith between them. Hence, a SE occupying a central location in a network is likely to be perceived as trustworthy by exchange partners in the network (Tsai \& Ghoshal, 1998). Therefore, the risk of opportunism may be averted, if a SE has more network relationship (Mysen et al., 2011). When SEs and its exchange partners are satisfied with each other, they will have more confidence and a sensitive expectation that their future dealings with each other will be positive which will minimize the temptation to take advantage of each other. According to the closure argument of Granovetter (1985), dense networks increase social control, develop common norms, and provide the possibility of punishment - in the case of misbehaviour - such as the loss of a good reputation or removing from future trade possibilities. The better this informal mechanisms work in the network structure, the lower the incentive to opportunism (Henningsen \& Henning, 2013; Richman, 2006). Thus, opportunistic behaviour of exchange partners decreases if the SE has a greater ability to access information through network relationship. Therefore, the study hypothesises that:

$\mathrm{H}_{1}$ : SSC of the owner of SE relates negatively to the opportunism of exchange partners

\section{RSC and Opportunism}

Rindfleisch and Heide (1997) highlighted that relational ties (strong ties, bonding and bridging) facilitate to control and avoid opportunism of exchange partners. Relational ties support mitigate TC by making opportunism more costly. Gulati and Singh (1998) explained that the costs of opportunistic behaviour in a network aggravate because the damage to one's reputation can influence not just the specific alliance in which one behaved opportunistically, but all other current and potential alliance partners. Relational ties help mitigate opportunism by making it more likely that such behaviour will be discovered and that the information will spread rapidly through the members of network (Joskow, 1985). Reputation takes time to build but it can be destroyed quickly, and relational ties create strong disincentives for opportunistic behaviour (Gulati \& Singh, 1998).

Relational ties are important sources to get information about potential exchange partners whether they are capable and reliable (Lu, 2007). Each partner has greater knowledge about the other's resources and greater confidence in their 
mutual assessments (Gulati \& Singh, 1998). SEs can consult via relational ties in the network to know in advance if the potential exchange partners are honest and reliable (Lu, 2007). They can search and contact reliable exchange partners with information accessed by bridging and linking ties. SEs can access information through their network to see whether they have selected the right exchange partner to carry out a transaction (Gulati \& Singh, 1998). Thus, relational ties can be used to reduce the potential risk of opportunistic behaviour of exchange partners (Carey \& Lawson, 2011; Granovetter, 1985).

Morgan and Hunt (1994) suggest that trust exists when a firm has confidence of the reliability and integrity in exchange partners. Dahlstrom and Nygaard (1999) develop a theoretical model to study opportunism as a determinant of TC and implicate cooperation and formalization as control structures that alleviate opportunism. Achrol and Gundlach (1999) empirically examined the effects of contract and trust safeguard against opportunism and found that social safeguards are useful means of alleviating opportunism. However, Heide and John (1990) argue that TCE has been justly criticized for its opportunism assumption. They assert that inter-personal trust challenge this assumption and mitigate opportunistic behaviour. While they acknowledge that opportunism is possible in any economic exchange relationship, they maintain that trust can complement control mechanisms to assure mutually beneficial exchanges (Judge \& Dooley, 2006). Heide and John (1992) highlighted that relational exchange limits opportunism through the sharing of the values of inter-personal trust. In contrast, some scholars (Achrol \& Gundlach, 1999; Dahlstrom \& Nygaard, 1999; Dwyer, Paul, \& Oh, 1987) highlighted the importance of relational norms which can be used as an alternative safeguard mechanism against opportunism. In the absence of trust and norms, information sharing on costs or new ideas/ technologies is unlikely because this information could be used opportunistically (Dyer \& Singh, 2003; Uzzi, 1997).

Scholars generally agree that increasing the relational content of an exchange can encourage cooperation between parties and thereby discourage opportunistic behaviour (Noordeweir, John, \& Nevin, 1990). Solidarity also causes exchange partners to be more supportive and cooperative towards each other (Dant \& Schul, 1992; Paswan \& Young, 1999). Under role integrity, exchange parties would behave properly and adequately in all circumstances (Misztal, 1996). Paswan and Young (1999) suggested that if role integrity exists in a business relationship, 
formal rules are not required. From this proposition it is possible to understand that role integrity has an inverse relationship with opportunism.

Boyle, Dwyer and Gassenheimer (1992) observed an inverse relationship between reciprocity and opportunistic behaviour. Moreover, they observed that channel partners used reciprocity as a substitute for more costly opportunism governing mechanisms. Gundlach, Achrol, and Mentzer (1995) found that channel partners became more committed due to reciprocity. That creates a mutual dependence between exchange partners. As a result of this mutual dependence, they cannot behave opportunistically towards each other. According to Boyle, Dwyer, Robicheaux and Simpson (1992), reciprocity prevents the use of threats by exchange partners. Since threats are a form of opportunism, this statement by Boyle et al. (1992) means reciprocity lowers opportunism.

Considering the SEs in Sri Lanka, informal social relationships are more powerful since there is no favourable transaction environment developed (Priyanath \& Premaratne, 2015). Business transactions are mostly based on interpersonal trust and norms and are embedded in informal relationships. In the Sri Lankan context, social values embedded within the relationships sometimes are stronger than the short term financial benefits which avert the opportunistic behaviour. Thus, the quality of the relationship between SEs and exchange partners strengthens both parties and discourages them to behave opportunistically. Therefore, the study predicts that:

$\mathrm{H}_{2}$ : RSC between the owner of SE and the members of the network relates negatively to the opportunism of exchange partners

\section{CSC and Opportunism}

Network members play a vital role in facilitating processes of information sharing and learning among firms. Especially, for SEs, strong networking is essential for the exchange of knowledge. When network members have the same perceptions about their mutual success, for an example, they can avoid their possible opportunism and have supported each other exchanging their ideas, opinions and resources very freely (Tsai \& Ghoshal, 1998). With a common understanding, network members are motivated to trust one another, as they can expect that they all work for collective goals and will not be hurt by any other member's pursuit of self-interest (opportunistic behaviour) (Miller, Besser, \& Weber , 2010). Thus, common understanding provides the harmony of interest that erases the possibility of opportunistic behaviour (Tsai \& Ghoshal, 1998). Thus, the 
CSC helps avert opportunism of exchange partners of SEs. Common understanding leads to share information and as a result, SEs can identify exchange partners' reliability and capability in advance, and it enables to safeguard a transaction from opportunism. Common understanding discourages opportunism if network members have strong CSC; they will support each other which facilitate to decrease the possible opportunistic behaviour. Therefore, the study proposes that:

$\mathrm{H}_{3}$ : CSC of the owner of SE negatively relates to the opportunism of exchange partners

\section{Methodology}

Quantitative approach is employed to study the research problem and the survey method was selected to gather data. Only owner managed manufacturing SEs, which are classified according to 2-digit levels of International Standard Industrial Classification-Revision 4 (United Nations, 2008), were selected to gather data. The Department of Census and Statistics (DCS) of Sri Lanka defines SEs as 'an establishment with 5 - 24 persons engaged' and the same definition was used to select SEs for the survey. According to the DCS, there were 71,126 SEs dispersed in Sri Lanka, and the study employed those SEs as the study population.

Multi-stage sampling method was adopted to determine the sample. Firstly, the study selected only the enterprises classified under the manufacturing category as the sampling frame. According to the Economic Census in 2013/2014, there were 14,185 industries belonging to the category of manufacturing establishments. Secondly, using the sampling frame (14,185 of SEs), 373 of units were selected using the sample size determination formula developed by Krejcie and Morgan (1970) with 95 percent confidence level and 5 percent margin of error. Thirdly, the sample is distributed according to the percentage share of the SEs located in each district and the number of firms was determined to represent all the districts in Sri Lanka. Then, SEs of each districts were listed out according to ISIC category and the sample was selected using the stratified sampling method to represent all the manufacturing industrial divisions.

The study used a two-step procedure to develop the questionnaire. Initially, a pool of items of each dimension was generated through the review of empirical literature and items which are more relevant to measure the particular dimension of the constructs were carefully selected. Thus, the questionnaire items were designed systematically based on literature published in cited journals. Each item was 
measured at an ordinal level with 7-point Likert scales (1 - Strongly disagree; 2 Disagree; 3 - Somewhat disagree; 4 - Neither agree nor disagree; 5 - Somewhat agree; 6 - Agree; 7 - Strongly agree). Each respondent was asked to state their agreement to the statements using these rankings. Then, a pilot survey was conducted prior to the main questionnaire survey in order to verify whether the questions are understood; whether instructions are clear; whether the order of the questions is appropriate and the questions are uninspiring etc. This helped to increase the validity and the reliability of the study. Data were collected for the questionnaire conducting face-to-face interviews. The unit of analysis is each owner of the SEs because the owner is the 'entrepreneur' in many small enterprises who starts and manages the business.

Partial Least Square - Structural Equation Modeling (PLS-SEM) was used to test the hypothetical relationships because it helps to examine the interrelationship between multiple independent and dependent variables and facilitates the evaluation of relationships between more than one construct simultaneously. The measurement model is evaluated employing reliability and validity tests and the efficiency of the structural model was evaluated by multi-collinearity issues, $R^{2}$, effect size $\left(f^{2}\right)$ and predictive relevance $\left(\mathrm{Q}^{2}\right)$. The smartPLS (version 2) software was used to analyze data.

\section{Measures}

SSC. The study assessed SSC using network size and network density. The network size of the owners of SEs is simply defined as the number of persons that SEs is directly connected to. This measurement was adopted by Bhagavatula (2009), Greve and Salaff (2003), Priyanath and Premaratne (2015). The network density of the owner of SE is simply defined as the total number of persons that the owner of SE deals business activities with and obtains support such as information, resources and moral support. The network density is measured as the percentage of close relationships within the total number of possible relationships of the owner of SE. This is adopted by Bhagavatula (2009); Burt (1992); Priyanath and Premaratne (2015).

$R S C$. The study considers the RSC as assets embedded with strength and quality of relationships. It refers to the kinds of relationships that the actor has developed with each other through a history of interactions (Patulny \& Svendsen, 2007; Silkoset, 2013). Considering the SEs, the RSC refers to the strength of relationships that SEs 
have developed with each other and the quality of relationship including interpersonal trust and relational norms embedded with the relationships.

The strength of the relationship is measured using the Network Strength Index. It refers to what extent owner of SE maintains close ties with regular interaction in a long period. The study uses an index to measure the network strength. Lu et al. (2012) adopted the same index. The study asked respondents to select the most important 12 members of different categories of the network and provide answers to the following questions. How well do you know the person (very well, somehow, or very little)? How often do you contact this person (daily, weekly, or monthly)? How many years have you known this person? For the first two questions, a weight of 1 , for answers of "very well" and "daily", 0.5, for "somehow" and "weekly", and 0.1, for "very little" and "monthly" were assigned. The network strength index was created by multiplying the three answers. The higher this value is, the stronger the ties are.

Ganesan (1994) represented trust as a two-dimensional construct of credibility and benevolence (behavioural dimension). Inter-personal trust refers to the belief of the entrepreneur that the network member is creditable (honest, flexible, fair and in no circumstance will purposely do anything to damage the relationship) and always shows the creditability by action (benevolence). Accordingly, creditability is evaluated employing three components i.e. reliability, predictability, and fairness and three items are used to measure benevolence, all of which have been adopted by Ganesan (1994); Lu et al. (2012); Moran (2005); Zaheer et al. (1998).

The study defines relational norms as the expectations about the behaviour that are at least partially shared informal agreements between parties that have been shown to govern their relationships. Relational norms between the owner of SE and network members are measured using five variables; information exchange, flexibility, solidarity, role of integrity and reciprocity. These variables have been adopted by Anderson and Weitz (1992), Doucette (1996), Dyer and Chu (2003), Heide and John (1992), and Rokken et al. (2003).

CSC. The CSC refers to the resources that provide a shared representation, an interpretation and systems of meaning. This dimension includes attributes such as common understanding, common perspectives and shared congruence, or generally agreed upon meanings (Nahapiet \& Ghoshal, 1998). CSC is embodied in attributes like a shared code or a shared paradigm that facilitates a common understanding of 
collective goals. A shared goal embodies the collective goals and aspirations among the network members (Miller et al., 2010).

Business Opportunism. Business opportunism of exchange partners was measured using eight items: exaggeration of needs, sincerity in dealings, truthfulness in dealings, good faith bargaining, dishonesty in dealings, unfair in dealing, cheat in dealing and breach of agreement engaged in by the exchange partner. Those items were adopted Dahlstrom and Nygaard (1999), Archol and Gundlach (1999), Mysen et al. (2011), and Rokkan et al. (2003).

\section{Results}

In this section, reliability and validity will be discussed first, followed by the results relating to the structural model.

\section{Reliability and Validity}

Based on PLS-SEM measurement of outer model, firstly, the study evaluated 12 of first order latent variables. Table 1 shows standardized factor loadings which were higher than the minimum threshold criterion 0.7 confirming the indicator reliability of first order reflective constructs. In addition, Table 1 further shows that all the factor loadings were statistically significant at 0.05 significance level. The Cronbach's $\alpha$ was higher than the required value of 0.7 and composite reliability was higher than the recommended 0.7 value. A higher value of the Cronbach's $\alpha$ and the composite reliability confirm the convergent validity of the first order constructs. Regarding the discriminant validity, none of the inter-construct correlation value was above the square-root of the Average Variance Extracted (AVE) and satisfied the criterion of the discriminant validity of first order constructs.

\section{Table 1: Analysis of the First Order Constructs}

\begin{tabular}{lccccc}
\hline Construct & Loading & $\boldsymbol{t}$-stat & CR & AVE & $\boldsymbol{\alpha}$ \\
\hline 1. Buyers' Opportunism & & & $\mathbf{0 . 9 7 0}$ & $\mathbf{0 . 7 8 4}$ & $\mathbf{0 . 9 6 5}$ \\
Exaggeration of needs & 0.822 & 41.52 & & & \\
Sincerity in dealings & 0.908 & 80.49 & & & \\
Truthfulness in dealings & 0.823 & 40.66 & & & \\
Good faith bargaining & 0.898 & 69.98 & & & \\
Break of agreement & 0.917 & 94.61 & & & \\
Dishonest in dealings & 0.811 & 39.82 & & & \\
Cheating dealings & 0.918 & 93.44 & & & \\
Unfair in dealings & 0.926 & 109.32 & & & \\
\hline
\end{tabular}




\begin{tabular}{lccccc}
\hline Construct & Loading & $\boldsymbol{t}$-stat & CR & AVE & $\boldsymbol{\alpha}$ \\
\hline 2. Suppliers' Opportunism & & & $\mathbf{0 . 9 6 5}$ & $\mathbf{0 . 7 5 3}$ & $\mathbf{0 . 9 5 8}$ \\
Exaggeration of needs & 0.841 & 43.38 & & & \\
Sincerity in dealings & 0.863 & 48.86 & & & \\
Truthfulness in dealings & 0.819 & 34.57 & & & \\
Good faith bargaining & 0.874 & 50.86 & & & \\
Break of agreement & 0.888 & 64.16 & & & \\
Dishonest in dealings & 0.783 & 34.97 & & & \\
Cheating dealings & 0.914 & 93.88 & & & \\
Unfair in dealings & 0.933 & 108.61 & & &
\end{tabular}

\section{Network Density}

DENS social net

DENS business net

DENS supportive net

$\begin{array}{ll}0.872 & 77.26 \\ 0.847 & 48.79 \\ 0.855 & 53.19\end{array}$

$\begin{array}{lll}0.892 & 0.735 & 0.820\end{array}$

\section{Network Size}

NSIZE social net

$0.853 \quad 59.44$

NSIZE business net

$0.871 \quad 80.40$

NSIZE supportive net

$0.855 \quad 60.13$

\section{Inter-personal Trust (Creditable)}

I feel that buyers are honest

0.884

0.940

0.735

0.923

I feel that suppliers are honest

0.881

67.45

I feel that buyers are trustworthy

0.896

76.05

I feel that suppliers are trustworthy

0.868

107.53

Buyers do not break promises

0.944

69.04

Suppliers do not break promises

0.942

165.61

Buyer are flexibility

0.929

173.42

Suppliers are flexibility

0.927

122.99

Buyers treat fairly for me

0.937

117.48

Suppliers treat fairly for me

0.930

153.37

I am sure that buyers would not

0.930

117.89

knowingly do anything to hurt me

I am sure that suppliers would not

$0.925 \quad 110.66$

$\begin{array}{lll}0.881 & 0.712 & 0.798\end{array}$

$\begin{array}{lll}0.940 & 0.735 & 0.923\end{array}$

knowingly do anything to hurt me 


\begin{tabular}{|c|c|c|c|c|c|}
\hline Construct & Loading & $t$-stat & $\mathbf{C R}$ & AVE & $\alpha$ \\
\hline \multicolumn{3}{|c|}{ 6. Inter-personal Trust (Benevolence) } & 0.941 & 0.842 & 0.906 \\
\hline $\begin{array}{l}\text { Buyers cares me giving higher } \\
\text { attention for my request }\end{array}$ & 0.913 & 91.72 & & & \\
\hline $\begin{array}{l}\text { Suppliers cares me giving higher } \\
\text { attention for my request }\end{array}$ & 0.917 & 103.14 & & & \\
\hline $\begin{array}{l}\text { Buyer sacrifice time, energy and } \\
\text { resources to fulfil my request }\end{array}$ & 0.828 & 55.11 & & & \\
\hline $\begin{array}{l}\text { Supplier sacrifice time, energy and } \\
\text { resources to fulfil my request }\end{array}$ & 0.825 & 53.97 & & & \\
\hline
\end{tabular}

\section{Norm of Information Exchange}

$\begin{array}{lll}0.926 & 0.760 & 0.894\end{array}$

Buyers provide useful information

$0.719 \quad 23.02$

Suppliers provide useful information

$0.795 \quad 32.80$

Suppliers provide information which helps us to plan and organize transaction activities in

$0.711 \quad 19.56$

advance

Buyers support me providing confidential information $0.712 \quad 30.41$

Suppliers support me providing confidential information

$0.705 \quad 30.38$

\section{Norm of Flexibility}

0.941

0.888

0.874

Buyers are flexible to change the promises and agreements

Suppliers are flexible to change the promises and agreements

Buyers do not force me to perform previous promises or agreement

Suppliers do not force me to perform previous promises or agreement

$0.879 \quad 65.02$




\begin{tabular}{lccccc}
\hline Construct & Loading & $\boldsymbol{t}$-stat & CR & AVE & $\boldsymbol{\alpha}$ \\
\hline $\begin{array}{l}\text { 9. Norm of Solidarity } \\
\text { Buyers are not behaving } \\
\text { opportunistically }\end{array}$ & 0.886 & 84.72 & & & \\
$\begin{array}{l}\text { Suppliers are not behaving } \\
\text { opportunistically }\end{array}$ & 0.878 & 73.21 & & & \\
$\begin{array}{l}\text { Buyers are willing to find possible } \\
\text { solution for unexpected problems }\end{array}$ & 0.922 & 91.31 & & \\
$\begin{array}{l}\text { Suppliers are willing to find } \\
\text { possible solution for unexpected } \\
\text { problems }\end{array}$ & 0.900 & 91.73 & & \\
$\begin{array}{l}\text { Buyers are willing to continue the } \\
\text { relationship }\end{array}$ & 0.925 & 117.05 & & \\
$\begin{array}{l}\text { Suppliers are willing to continue } \\
\text { the relationship }\end{array}$ & 0.934 & 141.30 & & \\
\end{tabular}

\section{Norm of Role of Integrity}

Buyers do not try to gain benefits

which harm to the relationship

$0.849 \quad 63.73$

Suppliers do not try to gain

benefits which harm to the

$0.849 \quad 56.84$

relationship

Buyers do not engage in cheating

$0.857 \quad 66.28$

Suppliers do not engage in

cheating

$0.894 \quad 82.58$

\section{$\begin{array}{lll}0.886 & 0.795 & 0.743\end{array}$}

\section{Norm of Reciprocity}

Buyers ignore unexpected

mistakes

Suppliers ignore unexpected

mistakes

0.880

73.31

$\begin{array}{lll}0.858 & 0.751 & 0.669\end{array}$

$0.892 \quad 87.92$

\section{Shared Vision}

Share common ambitions

Avoid distress

Share new business opportunities

$(n=373)$

The second-order constructs were developed using latent variable scores of the first-order constructs. Indicator reliability of four latent variables at the second order 
level in the hierarchical model were evaluated. All path coefficients (standardised factor loadings) were well above the threshold value 0.7 (see Table 2). The bootstrapping procedure was conducted to estimate the significance of each path coefficient by examining the $t$-statistics. All the $t$-statistics were significant at 0.05 significance level (see Table 2). Hence, the results show a strong evidence for indicator reliability of the second order constructs. Table 2 displays that the Cronbach's $\alpha$ was higher than the required value of 0.7 and composite reliability was higher than the recommended 0.7 value. With a higher level of the Cronbach's $\alpha$ and composite reliability, the second order constructs were developed in a reliable manner. AVE for each construct was higher than the required value 0.5 . The results confirm the convergent validity of the second order construct (see Table 2). Discriminate validity of the second order constructs showed that none of the interconstruct correlation value was above the square-root of the AVE and satisfied the criterion of the discriminant validity of the second order constructs.

Table 2: Analysis of the Second Order Constructs

\begin{tabular}{lrrrrr}
\hline Construct & Loading & $\boldsymbol{t}$-stat & CR & AVE & $\boldsymbol{\alpha}$ \\
& & & & & \\
\hline 1. Opportunism (OPPO) & 0.949 & 147.92 & & & \\
OPPOB & 0.932 & 108.88 & & & \\
OPPOS & & & & & \\
& 0.911 & 7.89 & & & \\
\hline 2. Rational Ability (RA) & 0.934 & 7.92 & & & \\
ACCESS & 0.919 & 7.91 & & & \\
ASSESS & & & & & \\
DMA & & & $\mathbf{0 . 9 4 9}$ & $\mathbf{0 . 7 9 9}$ & $\mathbf{0 . 9 3 3}$ \\
& 0.933 & 125.91 & & & \\
\hline 3. Norms & 0.882 & 78.56 & & & \\
Flexibility & 0.815 & 33.50 & & & \\
Information Exchange & 0.877 & 55.79 & & & \\
Reciprocity & 0.936 & 148.11 & & & \\
Role of Integrity & & & & & \\
Solidarity & 0.970 & 270.63 & & & \\
& 0.969 & 256.31 & & & \\
\hline 4. Inter-personal Trust & & & & \\
Benevolence Trust & & & & & \\
Creditable trust & & & & & \\
\hline ( 373) & & & & & \\
\end{tabular}

$(n=373)$ 


\section{PLS-SEM Results}

The efficiency of the structural model was assessed using the five step approach suggested by Hair, Hult, Ringle and Sarstedt, (2013). First, Multi-collinearity issues were assessed. The study calculates VIF and tolerance level with the support of linear regression option in SPSS (version 21.0). Considering the collinearity between independent constructs and dependent constructs in the structural model, the results indicated that there are no multi-collinearity issues among variables. VIF values for all the path coefficients show minimal collinearity, ranging from 1.419 to 4.406. These values are significantly less than the recommended threshold value of 5.00. The tolerance levels range from 0.285 to 0.705 exceeding 0.20 . These results provide a strong evidence for the absent of multi-collinearity issues between the independent constructs and the dependent constructs in the structural model. Secondly, the study assessed the significance of the path coefficients using $\beta$ value and $t$-statistics. In view of both path coefficients and $t$-statistics, Table 3 shows that all the hypothetical relationships were significant. Thirdly, the explanatory power of the dependent variable was substantial $\left(\mathrm{R}^{2}=0.662\right)$. Fourthly, predictive relevance $\left(\mathrm{Q}^{2}\right)$ of rational ability is 0.579 which displays a substantial higher explanatory power.

Table 3: Path Coefficients and Significance

\begin{tabular}{ccccc}
\hline Hypothesis & Relationship & $\boldsymbol{\beta}$ & $\boldsymbol{t}$-stat & Result \\
\hline $\boldsymbol{H}_{\boldsymbol{1}}$ & SSC $\rightarrow$ Opportunism & $-0.238^{*}$ & 5.79 & Supported \\
$\boldsymbol{H}_{2}$ & $\mathbf{R S C} \rightarrow$ Opportunism & $-0.370^{*}$ & 7.23 & Supported \\
$\boldsymbol{H}_{3}$ & CSC $\rightarrow$ Opportunism & $-0.286^{*}$ & 4.15 & Supported \\
${ }^{*} p>0.01 ;(n=373)$ & & &
\end{tabular}

\section{Discussion}

Table 3 illustrates that the information accessed through SSC has a significant negative effect on the opportunistic behaviour of the exchange partners $(\beta=-0.238$ or 24 percent and $t$-value $=-5.79$ ) supporting hypothesis $\mathrm{H}_{1}$. Similar results were provided by the studies of Carey and Lawson (2011), Lu (2007) and Mysen et al. (2011) confirming that information access through the network structure mitigates the opportunistic behaviour of exchange partners. Okten and Osili (2004) and Ting, Chen, and Bartholomew (2007) explained that the network size helps to tap information in the external environment successfully and reduce information 
asymmetry. These ideas are further verified by the empirical results of the study. Similarly, Henningsen and Henning (2013) explained that the informal punishment systems, such as the loss of a reputation or removal from future transaction can be enforced through network relationships. Bergen, Dutta, and Walker (1992) showed that network ties help minimize information asymmetry and to lower the problem of hidden information and the opportunistic behaviour of exchange partners. The better these informal mechanisms work, the lower the incentive to opportunism (Henningsen \& Henning, 2013; Richman, 2006).

Table 3 shows that information access through RSC has a negative effect on opportunism ( $\beta=-0.370$ or 37 percent), as the regression coefficient is significant ( $t$-value $=7.23)$. Thus, hypothesis $\mathrm{H}_{2}$ is strongly proved by the results. Uzzi (1997) explained that information enables the exchange partners bounded by the strong ties to reach 'economies of time'. Uzzi (1997) argued that strong ties promote the transfer of complex knowledge which leads to mitigate opportunism. The results of the study justify that if SEs are rich in RSC; they have ability to access information, knowledge and obtain advice and opinion, and thereby they can mitigate opportunism. Kale et al. (2000) indicated that mutual trust creates a basis for learning and sharing information across the exchange interface and reduces opportunistic behaviour. Inter-personal trust has an effect on the knowledge in exchanging accurate, secret and important information (Stam, Arzlanian, \& Elfring, 2013). Inkpen and Tsang (2005) found that inter-personal trust and the relational norms have a positive impact on sharing information among network members. Anderson and Weitz (1992) found that the norm of information exchange provides each other information which they normally do not disclose to the common exchange parties. Dyer (1997) empirically observed that information exchange between the exchange partners reduced information asymmetry. Thus, many scholars (Carey \& Lawson, 2011; Gulati \& Singh, 1998; Joskow, 1985; Lu, 2007) have provided empirical evidences supporting that the RSC has an effect on the reduction of the tendency for opportunistic behaviour of exchange partners due to exchange of information.

Table 3 further shows that the CSC has a negative significant effect on opportunism. The results show that the CSC has a negative variance $(\beta=-0.286$ or 27.6 percent) of opportunism, as the path coefficient is negative significantly ( $t$ value $=4.15$ ). Thus, hypothesis, $\mathrm{H}_{3}$ is strongly supported by results. Members of the network do not tend to behave opportunistically, if the common understanding among the members of network exists (Miller et al., 2010). Chiu, Hsu, and Wang 
(2006) in their empirical study found that common understanding was positively related to the quality of information and the information sharing and thereby exchange ideas and opinions which promote mutual understanding. The results of this study show that common understanding among members helps to access and assess information which facilitates to mitigate opportunism. Common understanding facilitates the sharing of information, and as a result, a firm can identify exchange partners' reliability and capability in advance and it enables to safeguard the transaction from opportunism (Chiu et al., 2006). The members of the network do not fear pursuit of self-interest by any other member of the network if they have a common understanding (Tsai \& Ghoshal, 1998). Thus, the results explained that the CSC of the owner of SEs has a strong negative effect on mitigating opportunism of exchange partners.

\section{Conclusion}

The study analysed the effect of information accessed through social capital on mitigating opportunism of exchange partners. To achieve this aim, working hypotheses have been developed to test how information accessed through each dimension of SC affects the opportunism of SE in Sri Lanka by synthesising the SCT with the TCE. The results reveal that information accessed through all the dimensions of SC have a significant negative impact on mitigating opportunism. The study has made several contributions to the existing knowledge. Firstly, the study synthesised all the dimensions of SC and opportunism into a new framework. It explains how information accessed through the different dimensions of SC affect the mitigation of opportunism, and thus it extends the knowledge about the relative efficacy of theories into a different economic and social context. Secondly, this study makes important contributions to literature by providing empirical evidence related to SC of SEs in Sri Lanka. Thirdly, the critical issue faced by the SE sector is that the sector has higher mortality rate due to the limitations mostly reflected in TC. The study extends the application of the SCT with the TCE to understand an alternative solution for this critical issue. The empirical results provide sufficient evidence to understand the strength of social capital to govern economic activities rather than the market mechanism, conforming the complementary effect of SC in governing economic activities.

The study indicates that policy makers should develop a mechanism to create better relationships between SEs and new exchange partners (by organising network formation activities such as seminars, trade fairs etc., providing information about 
reliable or guaranteed exchange partners through a webpage of responsible agency) in order to access information which will help mitigate opportunism. The study also has implications for policymakers to develop approaches to provide necessary support to access information and resources through social relationships. Government agencies, private sector and NGOs can maintain information services (through web pages, providing broad brand connections for SEs) to access information and develop more connections among network members both in local and international markets.

\section{References}

Achrol, R. S., \& Gundlach, G. T. (1999). Legal and social safeguards against opportunism in exchange. Journal of Retailing, 75(1), 107-124.

Adler, P. S. (2001). Market, hierarchy, and trust: The knowledge economy and the future of capitalism. Organization Science, 12(2), 215-234.

Adler, P. S., \& Kwon, S. W. (2002). Social capital: Prospects for a new concept. The Academy of Management Review, 27(1), 17-40.

Agwu, M .O ,.\& Emeti, C. I. (2014). Issues, challenges and prospects of small and medium scale enterprises (SMEs) in Port-Harcourt City in Nigeria. European Journal of Sustainable Development, 3(1), 101-114.

Anderson, E., \& Weitz, B. (1992). The use of pledges to build and sustain commitment in distribution channels. Journal of Marketing Research, 29(1), $18-34$.

Artz, K. W., \& Brush, T. H. (2000). Asset specificity, uncertainty and relational norms: An examination of coordination costs in collaborative strategic alliances. Journal of Economic Behaviour and Organization, 42(4), 337-362.

Babaei, H., Ahmad, N., \& Gill, S. S. (2012). Bonding, bridging and linking social capital and empowerment among squatter settlements in Teheran, Iran. World Applied Sciences Journal, 17(1), 119-126.

Balakrishnan, S., \& Koza, M. P. (1993). Information asymmetry, adverse selection and joint-ventures. Journal of Economic Behaviour and Organization, 20(7), 99-117.

Bergen, M., Dutta, S., \& Walker, O. C. (1992). Agency relationships in marketing: A review of the implications and applications of agency and related theories. Journal of Marketing, 56(7),1-24.

Bhagavatula, S. (2009). Weaving social networks performance of small rural firms in India as an outcome of entrepreneurs' social and human capital (Unpublished doctoral dissertation), Visakhapatnam University, India. 
Boyle, B., Dwyer, F. R., Robicheaux, R. A., \& Simpson, J. T. (1992). Influence strategies in marketing channels: Measures and use in different relationship structures. Journal of Marketing Research, 29(4), 462-473.

Burt, R. (1992). Structural holes: The social structure of competition. Cambridge, Harvard University Press.

Bwalya, R., Mugisha, J., \& Hyuha, T. (2013). Transaction costs and smallholder household access to maize markets in Zambia. Journal of Development and Agricultural Economics, 8(9), 328-336.

Carey, S., \& Lawson, B. (2011). Governance and social capital formation in buyersupplier relationships. Journal of Manufacturing Technology Management, 22(2), 152-170.

Carmel, E., \& Nicholson, B. (2005). Small firms and offshore software outsourcing: High transaction costs and their mitigation. Journal of Global Information Management, 13(3), 33-54.

Chiu, C. M., Hsu, M. H., \& Wang, E. T. G. (2006). Understanding knowledge sharing in virtual communities: An integration of social capital and social cognitive theories. Decision Support Systems, 42(3), 1872-1888.

Chow, W. S., \& Chan, L. S. (2008). Social network, social trust and shared goals in organizational knowledge sharing. Information \& Management, 45(7), 458465.

Coleman, J.S. (1988). Social capital in the creation of human capital. The American Journal of Sociology, 94(12), 95-120.

Dahlstrom, R., \& Nygaard, A. (1999). An empirical investigation of ex-post transaction costs in franchised distribution channels. Journal of Marketing Research, 36(2), 160-170.

Dant, R. P., \& Schul, P. L. (1992). Conflict resolution processes in contractual channels of distribution. The Journal of Marketing, 56(1), 38-54.

Doucette, W. R. (1996). The influence of relational norms and trust on customer satisfaction in inter firm exchange relationship. Journal of Consumer Satisfaction, Dissatisfaction and Complaining Behaviour, 9(5), 95-103.

Dwyer, F. R., \& Gassenheimer, J. B. (1992). Relational roles and triangle dramas: Effects on power play and sentiments in industrial channels. Marketing Letters, 3(2), 187-200.

Dwyer, F. R., Paul, H., \& Oh, S. S. (1987). Developing buyer-seller relationships. The Journal of Marketing, 51(2), 11-27. 
Dyer, J. H. (1997). Effective inter firm collaboration: How firms minimize transaction costs and maximize transaction value. Strategic Management Journal, 18(7), 535-556.

Dyer, J. H., \& Chu. W. J. (2003). The role of trustworthiness in reducing transaction costs and improving performance: Empirical evidence from the United States, Japan, and Korea. Organization Science, 14(1), 57-68.

Dyer, J., \& Sing, H. (1998). The relational view: Cooperative strategy and sources of inter organizational competitive advantage. The Academy of Management Review, 23(4), 660-679.

Fatoki, O. (2011). The impact of human, social and financial capital on the performance of small and medium-sized enterprises (SMEs) in South Africa. Journal of Social Science, 29(3), 193-204.

Ganesan, S. (1994). Determinants of long-term orientation in buyer-seller relationships. Journal of Marketing, 58(2), 1-19.

Granovetter, M. (1983). The strength of weak ties: A network theory revisited. Sociological Theory, 1(2), 201-233.

Granovetter, M. (1985). Economic action and social structure: The problem of embeddedness. American Journal of Sociology, 91(3), 481-510.

Greve, A., \& Salaff, J. W. (2003). Social networks and entrepreneurship. Entrepreneurship, Theory \& Practice, 28(1), 1-22.

Gulati, R. (1995). Does familiarity breed trust? The implications of repeated ties for contractual choices in alliances. Academy of Management Journal, 38(8), 85112.

Gulati, R., \& Singh, H. (1998). The architecture of cooperation: Managing coordination costs and appropriation concerns in strategic alliances. Administrative Science Quarterly, 43(4), 781-814.

Gundlach, G.T., Achrol, R.S., \& Mentzer, J. T. (1995). The structure of commitment in exchange. Journal of Marketing, 59(2), 78-92.

Hair, J. F., Hult, G. T. M., Ringle, C.M., \& Sarstedt, M. (2013). A primer on Partial Least Squares Structural Equation Modelling (PLS-SEM). New York: Sage publication.

Heide, J. B., \& John, G. (1990). Alliances in industrial purchasing: The determinants of joint action in buyer-supplier relationships. Journal of Marketing Research, 27, 24-36.

Heide, J. B., \& John, G. (1992). Do norms matter in marketing relationships? The Journal of Marketing, 56(2), 32-44.

Henningsen, G. A., \& Henning, C. H. C. A. (2013). Networks and transaction costs. American Journal of Agricultural Economics, 94(2), 377-385. 
Hobbs, J. E. (1996). A transaction cost approach to supply chain management. Supply Chain Management, 1(2), 15-27.

Inkpen, A. C., \& Tsang, E. W. K. (2005). Social capital network, and knowledge transfers. Academy of Management Review, 20(1), 146-165.

Joskow, P. (1985). Vertical integration and long-term contracts: The case of coalburning electric generating plants. Journal of Law, Economics, and Organization, 1(2), 33-80.

Judge, W. Q., \& Dooley, R. (2006). Strategic alliance outcomes: A transaction cost economics perspective. British Journal of Management, 17(5), 23-37.

Kale, P., Singh, H., \& Perlmutter, H. (2000). Learning and protection of proprietary assets in strategic alliances: Building relational capital. Strategic Management Journal, 21(3), 217-

237.

Kitapci, I. (2016). Cognitive social capital as an interdisciplinary concept. International Journal of Economic Studies, 2(3), 13-23.

Li, Z., \& Luo, F. (2011). Research on the relationship among social capital, organizational learning and knowledge transfer performance. Journal of Software, 3(9), 1763-1770.

Lu, H. (2007). The role of guanxi in buyer-seller relationships in China (Unpublished doctoral dissertation). Wageningen University, China.

Lu, H., Feng, S., Trienekens, J. H., \& Omta, S. W. F. (2012). Network strength, transaction-specific investments, inter-personal trust, and relationship satisfaction in Chinese agrifood SMEs. China Agricultural Economic Review, 4(3), 363-378.

Miller, N. J., Besser, T. L., \& Weber, S. S. (2010). Networking as marketing strategy: A case study of small community businesses. Qualitative Market Research: An International

Journal, 13(3), 253-270.

Moran, P. (2005). Structural vs. relational embeddedness: Social capital and managerial performance. Strategic Management Journal, 26(5), 1129-1151.

Mysen, T., Svensson, G. R., \& Payan, M. (2011). Causes and outcomes of satisfaction in business relationships. US Marketing Intelligence \& Planning, 29(2), 123-140.

Nahapiet, J., \& Ghoshal, S. (1998). Social capital, intellectual capital, and the organizational advantage. Academy of Management Review, 23(2), 242-266.

Noordewier, T. G., John, G., \& Nevin, J. R. (1990). Performance outcomes of purchasing arrangements in industrial buyer vendor relationships. Journal of Marketing, 54(4), 80-93. 
Nooteboom, B. (1993). Firm size effect on transaction cost. Small Business Economics. 5, 283-295.

Paswan, A. K., \& Young, A. (1999). An exploratory examination of the relationship between channel support mechanisms and relational norms in an international context. Journal of Business \& Industrial Marketing, 14(5), 445-455.

Patulny, R. V., \& Svendsen, G. H. L. (2007). Exploring the social capital grid: Bonding, bridging, qualitative and quantitative. International Journal of Sociology and Social Policy, 27(2), 32-51.

Priyanath, H. H. S., \& Premaratne, S. P. (2015). Effect of social capital on transaction cost: A case study of small enterprises in Sri Lanka. International Journal of Arts and Commerce, 4(4), 127-140.

Priyanath, H. H. S., \& Premaratne, S. P. (2017a). Power of social capital on mitigating transaction cost of small enterprises in Sri Lanka: An empirical investigation. International Journal of Arts and Commerce, 6(4), 17-35.

Priyanath, H. M. S., \& Premaratne, S. P. (2017b). Impact of information accessed through social capital on rational ability of owner manager small enterprises in Sri Lanka. American Journal of Information Management, 2(2), 19-29.

Priyanto, E., Mazkie, M., \& Khusaini, M. (2014). Effects of asymmetric information, transaction cost to corporate governance, and public organization performance. IOSR Journal of Business and Management, 15(6), 14-27.

Putnam, R. D. (1995). Making democracy work: Civic traditions in modern Italy. Princeton: Princeton University Press.

Richman, B. D. (2006). How community institutions create economic advantage: Jewish diamond merchants in New York. Law and Social Inquiry. 31(2), 383420.

Rindfleisch, A., \& Heide, J. B. (1997). Transaction cost analysis: Past, present and future applications. Journal of Marketing, 61(4), 30-54.

Rokkan, A.I., Heide, J. B., \& Wathne, K. H. (2003). Specific investments in marketing relationships: Expropriation and bonding effects. Journal of Marketing, 40(2), 210-224.

Silkoset, R. (2013). Negative and positive effects of social capital on co-located firms' withholding efforts. European Journal of Marketing. 47(2), 174-197.

Spraakman, G. (1997). Transaction cost economics: A theory for internal audit. Managerial Auditing Journal, 12(7), 323-330.

Stam, W., Arzlanian, S., \& Elfring, T. (2013). Social capital of entrepreneurs and small firm performance: A meta-analysis of contextual and methodological moderators. Journal of Business Venturing, 21(3), 103-128. 
Ting, S. H., Chen, C. N., \& Bartholomew, D. E. (2007). An integrated study of entrepreneurs' opportunism. Journal of Business \& Industrial Marketing, 22(5), 322-335.

Tsai, W., \& Ghoshal, S. (1998). Social capital and value creation: The role of intra firm networks. The Academy of Management Journal, 41(4), 464-476.

United Nations. (2008). International standard industrial classification of all economic activities - Revision 4. Retrieved from https://unstats.un.org/unsd/ publication/seriesm/seriesm_4rev4e.pdf

Uzzi, B. (1997). Social structure and competition in inter-firm networks: The paradox of embeddedness administrative. Science Quarterly, 42(3), 35-67.

Williamson, O. E. (1993). Calculativeness, trust, and economic organization. Journal of Law and Economics. 34(2), 453-500.

Williamson, O. E. (1985). The economic institutions of capitalism: Firms, markets and relational contracting. New York: Free Press.

Williamson, O. E. (1981). The economics of organization: Transaction costs approach. American Journal of Social, 87(3), 548-577.

Williamson, O. E. (1979). Transaction costs economics: The governance of contractual relations. Journal of Law and Economics, 22(2), 233-261.

Wu, W. P., \& Choi, W. L. (2005). Transaction cost, social capital and firms' synergy creation in Chinese business networks: an integrative approach. Asia Pacific Journal of Management, 21(3), 325-343.

Yenidogan, T. G. (2013). The impact of transaction attributes and trust on ex-post opportunism. International Journal of Management Sciences and Business Research, 2(6), 39-44.

Zaheer, A., McEvily, B., \& Perrone, V. (1998). Does trust matter? Exploring the effects of inter-organizational and inter-personal trust on performance. Organization Science, 9(2), 141-159.

Zaheer, A., \& Venkatraman, N. (1995). Relational governance as an interorganizational trategy: An empirical test of the role trust in economic exchange. Strategic Management Journal, 19(5), 373-392. 